\begin{tabular}{||l|l|l||}
\hline \multicolumn{2}{|c|}{ PublisherInfo } \\
\hline \hline PublisherName & $:$ & Palgrave Macmillan UK \\
\hline \hline PublisherLocation & $:$ & London \\
\hline \hline PublisherImprintName & $:$ & Palgrave Macmillan \\
\hline \hline
\end{tabular}

\title{
Time series analysis of the Labour Force Survey longitudinal data sets
}

\begin{tabular}{||l|l|l||}
\hline \multicolumn{2}{|c||}{ ArticleInfo } \\
\hline ArticleDOI & $:$ & $10.1057 /$ palgrave.elmr.1410012 \\
\hline \hline ArticleCategory & $:$ & Feature \\
\hline \hline ArticleFirstPage & $:$ & 48 \\
\hline \hline ArticleLastPage & $:$ & 53 \\
\hline \hline ArticleHistory & & RegistrationDate : 2007-1-15 \\
\hline \hline ArticleCopyright & $:$ & OnlineDate 2007-1-15 \\
\hline \hline
\end{tabular}


Catherine Barham, ${ }^{\text {Aff1 }}$

Nasima Begum, ${ }^{\text {Aff1 }}$

Aff1 Office for National Statistics

\section{Gives some background to how these data sets are constructed and looks at the benefits of this data source in analysing changes over time.}

This article gives some background to how the Labour Force Survey longitudinal data sets are constructed and looks at the benefits of this data source in analysing changes over time. The strength of the data is in looking at the flows of peoplebetween the three main economic activity states and this provides the main focus for the article. Changes in the proportions remaining in the same categories over the two time periods, along with changes in the size of the flows between the threemain categories are investigated, and some broad conclusions drawn about their causes. Some background is also given to the methodological issues which users should be aware of when using the longitudinal data sets.

Misc

The Full Text of this article can be found on the National Statistics website (http://www.statistics.gov.uk/elmr/01_07/downloads/ELMR01_07Barham.pdf). 